statement. A disciplinary meeting took place in June 2007 and the claimant was dismissed. He appealed and was reinstated. A 'review meeting' was held in September 2007, which was, in fact, a disciplinary meeting at which the parties discussed the claimant remaining in post. It was concluded that the necessary relationship of trust had broken down between the bishop and the claimant and he was dismissed. The employment tribunal had to decide whether the DBF had acted reasonably in treating the breakdown in the relationship as justification for the claimant's dismissal. The tribunal was concerned that, in June 2007, at a private meeting between a representative of the DBF and the bishop, the bishop had expressed the view that the relationship had broken down and that the claimant's position was untenable. This was never disclosed to the claimant. The tribunal further concluded that the investigation into the allegations against the claimant was inadequate. The main concern had arisen out of the accusation that the bishop was a liar. No steps had been taken to canvass this issue with the bishop. The consequence was that there was no adequate evidence before the DBF's representative upon which he could conclude that the claimant's assertion was untrue. In those circumstances, the tribunal concluded, any reasonable employer would have to proceed on the basis that the claimant was correct and that the bishop had, indeed, lied. A problem had clearly arisen in the relationship between the bishop and the claimant. If the reason for the problem was the fact that the claimant had complained of the wholly improper treatment by the bishop and the DBF had not undertaken sufficient investigation to establish otherwise, the tribunal concluded that the complainant's dismissal was unreasonable. By agreement, a sum of $£ 22,000$ was paid in settlement. [JG]

doi:10.1017/So956618Xo9001847

\title{
R (on the application of Baiai) v Secretary of State for the Home Department
} House of Lords: Lords Bingham, Rodger, Brown, Neuberger and Baroness Hale, July 2008

Immigration - right to marry - discrimination - human rights

The Secretary of State appealed against a decision that a scheme established under section 19 of the Asylum and Immigration (Treatment of Claimants, etc) Act 2004 involved a disproportionate interference with the respondents' right to marry under Article 12 of the European Convention on Human Rights. Section 19 applied to persons subject to immigration control and to all United Kingdom marriages save for Anglican marriages. The Secretary of State accepted that the distinction between Anglican and civil marriage contained within section 19 was discriminatory and undertook to remove it. Under the terms of section 19, the applicants were required to obtain the written permission of the Secretary of 
State before they could marry. Application for such permission required payment of a fee and permission would only be granted (in the absence of especially compassionate features) if the applicant had been granted the right to remain in the United Kingdom for at least six months and there were at least three months of that period remaining at the time of application. The House observed that the right to marry under Article 12 was a 'strong' right. National authorities were entitled to impose reasonable conditions on the right of a third-country national to marry for the purposes of ascertaining whether the marriage in question was a marriage of convenience and therefore not a genuine marriage warranting the protection of Article 12. Insofar as the scheme restricted the right to marry, it could only be justified to the extent that it operated to prevent marriages of convenience. In fact, the conditions imposed by the scheme had no relevance to whether the marriage was genuine or not. Rather, the scheme operated as a blanket prohibition (subject to the discretion in relation to the exception for especially compassionate features) on all marriages, whether genuine or not. As such, the scheme operated in such a way as to be a disproportionate interference with the right marry. The appeal was dismissed. [RA]

doi:10.1017/So956618X09001859

\section{Gallagher v Church of Jesus Christ of Latter-day Saints}

House of Lords: Lords Hoffman, Hope, Scott, Carswell and Mance, July 2008

Rating - public worship - freedom of religion - Mormon temple

The Church of Jesus Christ of Latter-day Saints (LDS) appealed against the decision that buildings (including a temple) on one of its sites did not qualify for the non-domestic rating exemption under Schedule 5 of the Local Government Finance Act 1988. The principle issues in the appeal were:

i. Whether the temple was a 'place of public religious worship' for the purposes of the 1988 Act (and therefore entitled to the exemption); and

ii. Whether the exclusion of the temple from such relief amounted to indirect discrimination in breach of Articles 9 and 14 of the European Convention on Human Rights.

The House dismissed the appeal, finding that the first issue had already been determined against the LDS by its earlier decision in Church of Jesus Christ of Latter-day Saints v Henning [1964] AC 420. There was no reason to suggest that Parliament intended the wording of the 1988 Act to hold a different meaning from the terms of its statutory predecessor under consideration in Henning. 